\title{
UČINKOVITOST BIOLOŠKI AKTIVNIH SASTAVNICA MATIČNE MLIJEČI: ANALIZA I STANDARDIZACIJA
}

\author{
Nada ORŠOLIĆ \\ Zavod za animalnu fiziologiju, Prirodoslovno-matematički fakultet, Sveučilište u Zagrebu, Zagreb, Hrvatska \\ Primljen u studenomu 2012. \\ CrossCheck u rujnu 2013. \\ Prihvaćen u siječnju 2013.
}

\begin{abstract}
Funkcionalna hrana postala je važan sektor u promicanju zdravstvenih prednosti hrane preko njenih funkcionalnih sastojaka sadržanih u ovim proizvodima. Posljednjih godina povećano je zanimanje potrošača i prehrambene industrije ne samo za funkcionalne sastojke hrane nego i za način na koji mogu pomoći u održavanju ljudskoga zdravlja. Mišljenje da prehrana ima važnu ulogu u sprečavanju i liječenju bolesti široko je prihvaćeno. Brojni literaturni podatci upućuju na to da pčelinji proizvodi, uključujući matičnu mliječ, mogu imati blagotvoran učinak na ljudsko zdravlje. Matična je mliječ pčelinji proizvod s brojnim biološki aktivnim sastojcima zdrave hrane. Izlučevina je posebnih žlijezda (hipofaringealnih i mandibularnih) koju pčele radilice (Apis mellifera L.) koriste za hranjenje matice i ličinki. Matična mliječ sadrži znatnu količinu proteina, slobodnih aminokiselina, lipida, vitamina i šećera. Njene su karakteristične sastavnice bioaktivne tvari, primjerice trans-10-hidroksi-2-decenska kiselina, antibakterijski proteini, i protein mase $350 \mathrm{kDa}$ protein, nazvan apisin, koji stimulira proliferaciju ljudskih monocita. Matična mliječ pokazuje brojne fiziološke i farmakološke učinke u sisavaca, uključujući vazodilataciju i sniženje krvnog tlaka, sniženje vrijednosti kolesterola, usporavanje procesa starenja, antioksidativnu aktivnost, imunomodulacijski te protuupalni, antimikrobni, estrogenski, antiosteoporozni i protutumorski učinak. Ublažavanje simptoma menopauze također je jedan od povoljnih učinaka matične mliječi. Ovaj pregledni članak upućuje na molekularne mehanizme uključene u razvoj pojedinih poremećaja te na odnos između matične mliječi i raznovrsnih bolesti na temelju dosadašnjih rezultata različitih in vivo i in vitro istraživanja. Rad također opisuje tumačenja mogućih mehanizama višestrukih korisnih učinaka matične mliječi u borbi protiv starenja i komplikacija povezanih sa starenjem. Osim toga, navode se i preporuke o definiranju standarda kakvoće matične mliječi s obzirom na to da rezultati analize ovoga pčelinjega proizvoda upućuju na značajne razlike u sastavu i djelotvornosti svježih i dehidriranih uzoraka.
\end{abstract}

KLJUČNE RIJEČI: funkcionalna hrana, kakvoća i standardizacija, kemijski sastav, pčelinji proizvod

Danas se u Europi sve više koristi pojam „funkcionalne hrane“, pod kojim se podrazumijeva sva hrana s biološki aktivnim djelovanjem koja pomaže očuvanju zdravlja i utječe na pojedine tjelesne funkcije. Funkcionalna je hrana preko svojih bioloških aktivnih sastavnica važan čimbenik u održavanju ljudskoga zdravlja; njena se važnost posebice očituje u održavanju homeostaze organizma, dobrobiti za organizam, uključujući kvalitetniji život, u sprječavanju ili liječenju lakših bolesti, održavanju ravnoteže razine biološki važnih tvari u organizmu, primjerice hormona, vitamina, aminokiselina i dr., te u održavanju mikroflore probavnog sustava i količine slobodnih radikala - glavnih uzročnika mnogih kroničnih patoloških stanja i bolesti.

Funkcionalna hrana može biti prirodna ili dobivena uklanjanjem ili izmjenom jedne ili više njenih sastavnica. Neke sastavnice mogu biti dodane hrani 
kako bi povećale "funkcionalnost ili dobrobit" namirnica; među njima su omega-3 masne kiseline, vitamini, probiotici, vlakna, biljni dijelovi ili sastavnice iz biljaka i bioaktivni peptidi i fitosteroli (1). U hranu s potencijalno zdravstvenim prednostima svrstava se i hrana podrijetlom iz košnice: med, propolis, pčelinji kruh, pelud i matična mliječ. Matična mliječ (MM) jedan je od najcjenjenijih pčelinjih proizvoda te se kao najatraktivnija funkcionalna hrana može koristiti i u medicini kao ljekoviti pripravak, posebno u dijetetici i kozmetici.

Mliječ je izlučevina posebnih žlijezda (hipofaringealnih i mandibularnih) koju pčele (Apis mellifera L., Apidae) koriste za hranjenje matice i ličinki. Tri su tipa mliječi: radilička mliječ, matična mliječ i trutovska mliječ. Mliječ je bijele boje, kiselog pH $(4,5$ do 5,0$)$ i specifična okusa. Smatra se da je diferencijacija jajašca u maticu ili radilicu posljedica različitog načina hranjenja ličinki s mliječi (2). U matičnoj mliječi ima deset puta više pantotenske kiseline, biopterina i neobiopterina nego u radiličkoj i trutovskoj mliječi. Tijekom razvoja ličinki radilica i trutova mijenja se odnos glukoza/fruktoza od 0,1 do 0,7 , a u matičnoj mliječi cijelo vrijeme ostaje isti i iznosi 1,2 do 2,5. Kamakura (2) jasno je pokazao da dimorfizam jajašca u maticu ili radilicu ne ovisi o genetskim razlikama nego o uzimanju matične mliječi. Diferencijaciju pčelinje ličinke $u$ maticu potiče protein rojalaktin (mase $57 \mathrm{kDa}$ ), sadržan u matičnoj mliječi. Rojalaktin povećava veličinu tijela i razvoj jajnika i skraćuje razvojno razdoblje pčela. Rezultati istraživanja pokazali su da rojalaktin aktivira p70 S6 kinaze odgovorne za povećanje tjelesne veličine, povećava aktivnost mitogenom aktivirane protein kinaze skraćujući razvojno razdoblje, te povećava titar juvenilnih hormona odgovornih za razvoj jajnika. Učinak rojalaktina u procesu diferencijacije pčelinje ličinke u maticu temelji se na signalnom putu posredovanom preko receptora epidermalnoga čimbenika rasta (EGFR).

Mnogo je tvrdnji o dobrobiti matične mliječi za ljudsku zajednicu, uključujući kvalitetniji život i liječenje lakših bolesti. Spektar djelovanja matične mliječi na organizam je višestruk te ga danas medicina prihvaća kao stimulativno i regenerativno sredstvo. Unatoč tome, mnoge od tih tvrdnji trebalo bi svakako detaljnije klinički istražiti i znanstveno dokazati.

\section{Kemijski sastav matične mliječi}

Matičnu mliječ čine voda (60 do 70) \%; proteini (10 do 18) \% (albumini, $\alpha, \beta, \gamma$ globulini, glikoproteini, lipoproteini, 23 aminokiseline); šećeri (9 do 15) \% (glukoza, fruktoza, neznatne količine riboze, maltoze, izomaltoze, gentiobloze, turanoze, trehaloze, neotrehaloze); lipidi (1,5 do 7) \% (fenoli, steroli i gliceroli, vosak, neutralne masti, fosfolipidi, slobodne organske kiseline); anorganske tvari $(0,7$ do 1,5$) \%$ (K, Na, Ca, Mg, Cu, Fe, Mn, Zn, Si, Cr, Ni, Ag, Co, $\mathrm{Al}, \mathrm{As}, \mathrm{Hg}, \mathrm{Bi}, \mathrm{Au}, \mathrm{S}, \mathrm{P}$ ); vitamini (336 do 351) mg $\mathrm{g}^{-1}\left(\mathrm{~B}_{1}, \mathrm{~B}_{2}, \mathrm{~B}_{3}, \mathrm{~B}_{5}, \mathrm{~B}_{6}, \mathrm{~B}_{7}, \mathrm{~B}_{9} \mathrm{~B}_{12}\right.$ pantotenska kiselina, biotin, folna kiselina, inozitol, vitamin $\mathrm{E}, \mathrm{D}, \mathrm{A}, \mathrm{K}, \mathrm{C}$ ) (3-5).

U mliječi se nalaze još i različiti enzimi (amilaza, invertaza, katalaza, kisela fosfataza i dr.), neuroprijenosnici (acetilkolin i kolin) i spolni hormoni (estradiol, testosteron, progesteron). Farmakološki učinci matične mliječi pripisuju se trans-10-hidroksi2-decenskoj kiselini, 10- hidroksidecenskoj kiselini, rojalizinu, apisinu i nekim antimikrobnim proteinima $(6,7)$. Osnovni sastav matične mliječi prikazan je u tablici 1.

Proteini matične mliječi čine oko polovine suhe tvari i uglavnom su topivi u vodi. Više od $80 \%$ topivih proteina, tzv. glavni proteini matične mliječi (MRJPs, engl. major royal jelly proteins) $(8,9)$, glavni su čimbenici odgovorni za specifičnu fiziološku ulogu matične mliječi u razvoju matice. Oni uključuju brojne esencijalne aminokiseline, slične ovalbuminu i kazeinu (8). U ranijim izvješćima, obitelj MRJP čini većinu topljivih proteina (31\%), ima devet članova; MRJPs 1-9 (10-12). MRJP 1 slabo je kiseli glikoprotein (pH 4,9 do 6,3; $55 \mathrm{kDa}$ ) koji tvori oligomere od 350 kDa ili $420 \mathrm{kDa}(13,14)$. MRJP 2, MRJP 3, 4 i MRJP 5 su glikoproteini od $49 \mathrm{kDa}, 60 \mathrm{kDa}$ do $70 \mathrm{kDa}, 60$ $\mathrm{kDa}$ i $80 \mathrm{kDa})(8,15)$. Fiziološka funkcija proteina matične mliječi opisana je u mnogobrojnim radovima (16-22). Neki od MRJPa stimuliraju proliferacije stanica (17-21), a neki pak inhibiraju bisfenolom Ainduciranu proliferaciju ljudskih staničnih linija raka dojke (22). Osim toga, MRJP 1 i 2 stimuliraju makrofage miša oslobađanjem TNF- $\alpha$ (9), a MRJP 3 modulira imunosni odgovor potiskivanjem proizvodnje IL-4, IL-2 i IFN- $\gamma$ u T-limfocitima (23, 24).

Sveukupno je u matičnoj mliječi uporabom jednodimenzionalne gel elektroforeze otkriveno 37 , a drugim analizama 22 neredundantna proteina, a 19 novih proteina nađeno je proteomičkim pristupom (15, 16). Glavne proteinske komponente matične mliječi su MRJPs i proteini vezani uz metabolizam ugljikohidrata, kao što su glukoza oksidaza, prethodnikglukozidaza i glukoza dehidrogenaza. Tih 19 novootkrivenih proteina uglavnom je svrstano u tri 
funkcionalne kategorije: oksido-redukcijski proteini, protein vezujući proteini i lipid prijenosni proteini.

Danas se matična mliječ intezivno istražuje, posebice u Japanu, te su mnoge pretpostavke njene učinkovitosti i znanstveno potvrđene. Osim što se rabi kao kozmetički i prehrambeno-dijetni dodatak, vjeruje se da ima i biostimulativni te regenerativni učinak na ljudsko zdravlje. Spektar korisnoga djelovanja matične mliječi na oporavak organizma te prevencija mnogih nefizioloških stanja pod njenim utjecajem temelji se na iznimnom kemijskom sastavu. Ipak, unatoč brojnim istraživanjima još nema dovoljno podataka o učinkovitosti matične mliječi u poboljšanju ljudskoga zdravlja. Biološki učinak matične mliječi istraživan je uglavnom na životinjskim pokusnim modelima i staničnim kulturama, a manje na ljudima. S obzirom na kompleksnost matične mliječi, u novijim se istraživanjima provodi pročišćivanje i proučavanje biološke učinkovitosti pojedinih bioaktivnih molekula koje ona sadrži.

S obzirom na izvanredne biološke značajke i njenu uporabu u mnogim sektorima, od farmaceutske i prehrambene industrije te proizvodnje kozmetičkih pripravaka, postoji potreba za standardizacijom matične mliječi te istraživanjem njenih kvalitativnih i kvantitativnih vrijednosti kroz vrednovanje različitih komponenti i provedbu analitičkih ispitivanja bioloških aktivnih sastavnica te njihovih promjena tijekom skladištenja i čuvanja.

\section{Matična mliječ, ljepota i odgoda starenja}

Salazar-Olivio i Paz-Gonzales (25) pokazali su da proteini matične mliječi mogu imati učinak u odgodi i sprječavanju starenja. Starenje je višeznačan proces na koji utječu brojni čimbenici; posebice se temelji na smanjenju stanične proliferacije i obnove tkiva te postupnoga gubljenja funkcije. Ti su autori pokazali da matična mliječ ima mitogeni učinak (potiče proliferaciju) na stanice kukaca u kulturi. Watanabe i sur. (21) mitogeni su učinak matične mliječi pokazali na stanicama U-937 (stanična linija ljudskih monocita) a pojačanu sintezu DNA i albumina u stanicama jetara potvrdili su Kamakura i sur. (17). Smatra se da matična mliječ sadrži čimbenike rasta ili hormone koji pospješuju stanični rast. Ti podatci potvrđuju kozmetičku učinkovitost matične mliječi zajedno s podatcima da pojedine proteinske sastavnice matične mliječi pojačavaju sintezu novih adhezijskih molekula na površini stanice. Drugi autori (26) pokazuju da matična mliječ može povećati životni vijek miševa $\mathrm{C} 3 \mathrm{H} / \mathrm{HeJ}$ kroz mehanizam koji se temelji na redukciji oksidativnih oštećenja. Već je odavno poznata teorija "slobodnih radikala i starenja"; reaktivni kisikovi radikali (ROS) nastali u stanicama rezultiraju skupnim oštećenjem stanice (27). Točnije, poremećaj ravnoteže između ROS proizvodnje i antioksidativne obrane određuje stupanj oksidativnoga stresa. Posljedice stresa uključuje promjene staničnih proteina, lipida i DNA. Rezultati brojnih istraživanja pokazali su da je starenje stanica i organizma posljedica nakupljanja povećane razine oksidativnih oštećenja jezgrine DNA; endogena oštećenja DNA uzrok su starenja i degenerativnih bolesti povezani sa starošću, primjerice tumora, srčanih bolesti i bolesti krvožilnoga sustava. Mutacije kao posljedica oksidativnih oštećenja skraćuju životni vijek. Iako je matična mliječ povećala preživljenje miševa za $50 \%$, autori smatraju da se mehanizam ne temelji na sakupljanju slobodnih radikala nego na obuzdavanju oksidativnoga oštećenja tkiva, moguće kroz ublaženje uvjeta kronične upale.

Koya-Miyata i sur. (28) pokazali su da matična mliječ ima učinak na proizvodnju kolagena $u$ fibroblastima kože te su izdvojili aktivnu sastavnicu pod nazivom čimbenik proizvodnje i promicanja kolagena. Kolagen je predominantni vlaknasti protein izvanstaničnoga matriksa i glavni protein vezivnoga tkiva u ljudskom tijelu. Oko $3 \%$ do $6 \%$ cjelokupnih proteina u tijelu čini kolagen, i funkcionalna svojstva kože ovise o cjelovitosti kolagena u dermi. Promjene u stupnju taloženja kolagena javljaju se tijekom zacjeljivanja rana, razvoja kosti i sa starenjem. Kontrola metabolizma kolagena posebice je važna u terapeutskoj i kozmetičkoj primjeni. Koya-Miyata i sur. (28) potvrdili su da su 10-hidroksi-2-decenska kiselina i 10-hidroksidecenska kiselina farmakološki aktivne sastavnice matične mliječi u proizvodnji kolagena. Te kiseline u prisutnosti askorbinske kiseline potiču stvaranje transformirajućega čimbenika rasta koji povećava proizvodnju kolagena, ovisno o dozi. Ostaje još nejasno utječu li te kiseline i na enzime ključne u sintezi kolagena (prolil hidroksilazu i lizil hidroksilazu). Danas se matična mliječ koristi u različitim preparatima. Njen se učinak temelji na ubrzanju oksidativnoga metabolizma te kataboličkih i anaboličkih reakcija izmjene tvari.

\section{Matična mliječ i njena učinkovitost na moždane stanice}

U svijetu, posebice u zapadnim zemljama danas bilježimo stalno povećanje broja starijih ljudi koje prati pad spoznajnih mogućnosti ljudi i porast neuropsihijatrijskih poremećaja poput Alzheimerove 
bolesti i depresije - dominantnih problema u starijoj populaciji. Rezultati nedavnih istraživanja sugeriraju da su neurotropni čimbenici uključeni u etiologiju i/ili razvoj tih bolesti i da pojačana sinteza neuropeptidnih čimbenika može biti obećavajući čimbenik u zaštiti od ovih bolesti. Hashimoto i sur. (29) otkrivaju da matična mliječ selektivno potiče ekspresiju mRNA neutrofičkoga čimbenika glija stanica (engl. glial cell line-derived neurothrophic factor; GDNF), koji djeluje na mozak i na filament $\mathrm{H}$, dominantni biljeg aksona u hipokampusu odraslih miševa. Utvrđeno je da dodatak egzogenoga GDNF čimbenika ima prije svega zaštitnu ulogu u borbi protiv smrti dopaminergični neurona, ishemičnih i traumatskih moždanih oštećenja. Ta opažanja sugeriraju da endogeni GNDF ima sličnu zaštitnu ulogu u borbi protiv neuroloških poremećaja kojih je danas sve više zbog starije populacije ljudi. Nedvojbeno je da su ta opažanja za GDNF obećavajući put prema zaštiti ili obradi neuroloških bolesti, posebice zato što će otkrivanje aktivnih sastavnica koje reguliraju ekspresiju i evoluciju učinka matične mliječi na moždane funkcije, kao što su učenje i pamćenje, pridonijeti boljoj primjeni matične mliječi u brizi za zdravlje i/ili u kliničkoj uporabi u liječenju neuroloških poremećaja. Hattori i sur. $(30,31)$ potvrđuju učinak matične mliječi i njene jedinstvene masne kiseline, 10-hidroksi-2-decenske kiseline, na neurogenezu neuralnih progenitorskih matičnih stanica in vitro. Matična miliječ olakšava diferencijaciju svih tipova moždanih stanica (neurona, astrocita i oligodendrocita). Uz to, 10-hidroksi-2-decenska kiselina povećava proizvodnju neurona a smanjuje proizvodnju astrocita. Neuralnim matičnim stanicama/ progenitorskim stanicama (NSCs) svojstveno je samoobnavljanje i mnogostruka aktivnost da se diferenciraju u neurone, astrocite i oligodendrocite. Oštećeni mozak ima mogućnost popravka preko aktiviranih NSCs-a. NSCs su cilj za liječenje Alzheimerovei/ili Parkinsonove bolesti. Razumijevanje biološke učinkovitosti matične mliječi na molekularnoj razini zasigurno će pridonijeti učinkovitoj zaštiti moždanih stanica i terapiji nekih neuroloških bolesti.

\section{Matična mliječ i šećerna bolest}

Matična mliječ sadrži sastavnice funkcionalno i strukturno slične inzulinu (32). Potvrđeno je da matična mliječ može potaknuti usmjeravanje preadipocita $u$ adipocite. Proces adipogeneze prije je posljedica adipogenih signala sadržanih u matičnoj mliječi nego njene inzulinske aktivnosti. Prema Erski-
Biljić (33) matična mliječ zauzima jedno od prvih mjesta na popisu terapeutskih pripravaka $\mathrm{s}$ regenerativnim značajkama: uočeno je da potiče regeneriranje oštećenih stanica gušterače, sprječavajući nastanak dijabetesa. Regeneracija stanica gušterače i očuvanje razine inzulina ključni su čimbenici za pad razine šećera u krvi (33). Nomura i sur. (34) potvrdili su na štakorskom modelu za tip 2 dijabetesa OLETF (engl. Otsuka Long-Evans Tokushima Fatty; OLETF) da bi dugotrajna primjena matične mliječi mogla biti učinkovita i funkcionalna hrana u sprječavanju razvoja inzulinske otpornosti (rezistencije).

\section{Protutumorska učinkovitost matične mliječi $i$ stimulacija hematopoieze}

Protutumorski učinak matične mliječi pripisuje se njenoj aktivnoj sastavnici 10-hidroksi-decenskoj kiselini te zasićenim dikarboksilnim kiselinama (sukcinska, glutarna, adipinska, pimelinska, suberinska, azelainska, sebacinska kiselina). Učinak matične mliječi za sada je istražen na $6 \mathrm{C}_{3}$ HED limfosarkomu, $\mathrm{TA}_{3}$ mamarnom karcinomu, ascitičnom Erlichovu karcinomu, leukemiji AKR miša, sarkomu 180, Erlichovu solidnom tumoru te na L1210 i P388 limfatičkoj leukemiji (35-38). Matična mliječ pokazala se učinkovitom u spororastućim tumorima, ali ne i u brzorastućima. Rezultati istraživanja što su ga proveli Oršolić i sur. (39-41) pokazuju da matična mliječ smanjuje broj tumorskih čvorića samo ako se daje istovremeno s tumorskim stanicama te da ima značajna imunomodulatorna svojstva (42). Matična mliječ potiče formiranje limfocita T odgovornih za imunosni odgovor protiv virusa i tumorskih stanica (43). Protutumorska učinkovitost matične mliječi pokazana je i na stanicama HeLa (karcinom vrata maternice), posebice izolirani proteinski odjeljak $\mathrm{RJP}_{30} \mathrm{~s} 50 \%$ citotoksičnošću.

Stanice Erlichova ascitičnog tumora (EAT) rastu brzo u većini sojeva miševa uzrokujući izrazito narušavanje hematopoietske i imunosne funkcije. Narušavanje hematopoietske $i$ imunosne funkcije uzrok je smrti domaćina čak i uz prisutnost malog broja tumorskih stanica. Erlichov ascitični tumor uzrokuje oštećenja u broju granulocitno-makrofagnih kolonija u slezeni i potiče stvaranje prirodnih supresorskih stanica. Fagociti, posebice makrofagi i neutrofili, imaju važnu ulogu u urođenoj i stečenoj imunosti odnosno u obrani domaćina protiv različitih infektivnih tvari i rasta tumora. Najvažnija značajka ovih stanica, potrebitih u imunosnoj reakciji posredovanoj stanicama i nespecifičnoj upalnoj 
reakciji, njihova je sposobnost da migriraju unutar upalnog područja. Istraživanja temeljena na životinjskim modelima pokazala su da tumorske stanice mogu proizvoditi čimbenike koji oštećuju upalni odgovor, omogućavajući rast tumora in vivo. Točnije, tumorske stanice mogu stimulirati supresornu aktivnost makrofaga u domaćinu. Osim nedostatne akumulacije fagocita u upalno mjesto, neke druge stanične odrednice promijenjene su u nositelja tumora, posebice odgovor granulocitno-makrofagnih kolonija na čimbenik aktivacije kolonija. Zanimljivo je da se obradom zdravih miševa matičnom mliječi nije povećao ni broj stanica koštane srži ni broj granulocitnomakrofagnih kolonija u slezeni kod primjene doze od $0,5 \mathrm{~g} \mathrm{~kg}^{-1} ; 1,0 \mathrm{~g} \mathrm{~kg}^{-1} ; \mathrm{i}$ 1,5 $\mathrm{g} \mathrm{kg}^{-1}$, a u miševa koji su nositelji EAT-a u preventivnoj obradi povećan je broj stanica koštane srži te broj klasičnih aktiviranih makrofaga (M1) u perifernoj krvi. Povećanje broja dugoživućih matičnih stanica u kulturi te veći broj granulocitno-makrofagnih kolonija opaženi su nakon obrade kulture stanica s matičnom mliječi, koja potiče oporavak makrofaga te povećava njihov broj i aktivnost. Oporavak hematološkoga poremećaja u miševa koji su nositelji EAT-a povezan je i s njihovim dužim preživljenjem. Pokazano je da makrofagi pridruženi tumoru (M2, alternativni makrofagi koji nastaju polarizacijom makrofaga tijekom upale) potiču i stimuliraju rast tumora te inhibiraju aktivnost NK stanica i T limfocita $(44,45)$. Očito neke od sastavnica matične mliječi sprječavaju supresorni učinak samog tumora na makrofage te pojačavaju imunomodulatornu aktivnost samih makrofaga koji postaju učinkovitiji u kontroli rasta i širenja tumorskih stanica. Matična mliječ štiti i od imunosupresije makrofaga prouzročene tvarima koje luče tumorske stanice; posebice se njen značaj očituje u inhibiciji razine prostaglandina $\left(\mathrm{PGE}_{2}\right)$, čimbenika koji inhibira tumoricidalnu aktivnost makrofaga. $\mathrm{PGE}_{2}$ mjenja imunosni odgovor uključujući mitogenezu limfocita $\mathrm{T}$, proizvodnju citokina te makrofagima i NK stanicama posredovanu citotoksičnost na tumorske stanice. Uz to, matična mliječ može inhibirati neke proupalne citokine, primjerice TNF- $\alpha$, IL-6, i IL-1 bez smanjenja citotoksičnoga učinka makrofaga stimuliranih s LPS i/ili LPS + IFN- $\gamma$ (44). Tako Bincoletto i sur. (45) smatraju da je smanjenje razine $\mathrm{PGE}_{2} \mathrm{u}$ miševa koji su nositelji EAT-a, obrađenima matičnom mliječi, glavni uzrok povećanju njihova preživljenja. Razvidno je da matična mliječ kao modifikator biološkog odgovora smanjuje mijelosupresiju i povećava antitumorsku učinkovitost. Rezultati naših istraživanja potvrđuju tu činjenicu na štakorima kao pokusnim modelima $(41,42)$. Inhibicija sinteze prostaglandina uporabom matične mliječi $\left(2,5 \mathrm{mg} \mathrm{mL}^{-1}\right)$ u makrofagima stimuliranima LPS + IFN- $\gamma$ bila je manja za $63 \% \mathrm{u}$ usporedbi s kontrolnom skupinom makrofaga. Takav rezultat daje nadu i mogućnost učinkovite primjene matične mliječi kao dodatka prehrani u cilju poboljšanja kvalitete života ljudi s autoimunim bolestima, poput reumatoidnog artritisa i upalnih crijevnih bolesti. Sastavnica matične mliječi koja stimulira proliferaciju ljudskih monocitanedavnoje izolirana i okarakterizirana kao glikoprotein mase $350 \mathrm{kDa}$ (apisin). Osim toga, zaštitni učinak matične mliječi na hematopoiezu potvrđen je u miševa ozračenih X-zrakama (46-48), gdje matična mliječ sprječava zračenjem prouzročena oštećenja matičnih stanica. Imunostimulativna svojstva matične mliječi združene s propolisom (pripravak nazvan Apinhalin) na proces granulocitopoeze i limfopoieze zapažena su nakon zračenja miševa dozom od 3 Gy i/ili 5 Gy. Brza obnova stanica bila je razvidna već nakon deset dana $u$ usporedbi s kontrolnom skupinom miševa (49). Nakaya i sur. (22) pokazali su aktivnost matične mliječi na okolišni estrogen utvrdivši da ona inhibira bisfenolom A-induciranu proliferaciju ljudskih staničnih linija raka dojke (MCF-7). Bisfenol A dobro je poznat okolišni estrogen; kemijski spoj s dvjema funkcionalnim skupinama fenola koji se uglavnom koristi za proizvodnju polikarbonatne plastike i poliepoksida. Bisfenol A uzrokuje poremećaje endokrinoga sustava oponašajući prirodne tjelesne hormone, čime može negativno utjecati na zdravlje, posebice žena $(50,51)$. Nadalje, matična mliječ može modulirati razinu oksidativnoga stresa i apoptozu u stanicama jetara i bubrega štakora obrađenih kemoterapeutikom cisplatinom. Profilaktički unos matične mliječi značajno smanjuje razinu malondialdehida (MDA) prouzročenog izlaganjem cisplatini u jetrima i bubregu. Antioksidativna sposobnost matične mliječi usko je povezana s njenim slobodnim aminokiselinama, kao što su aspartatna kiselina, L-cistein, cistin, tirozin, glicin, lizin, leucin, izoleucin i valin (52). Pozitivni učinak matične mliječi na antioksidacijski sustav vidljiv je i u povećanju razine glutationa (GSH), glutation peroksidaza (GSHPx), aktivnosti glutation-S-transferaza (GST) i superoksid dismutaza (SOD). Matična mliječ može smanjiti toksičnost induciranu tetraklormetanom, kadmijem i paracetamolom na jetrene stanice te ublažiti njihovu genotoksičnost i nefrotoksičnost (5355). Zbog svoje visoke kemijske reaktivnosti, reaktivni 
radikali kisika (ROS) nastali tijekom toksičnoga djelovanja tih spojeva uzrok su peroksidacije lipida i oksidacije DNA i proteina. Matična mliječ inhibira lipidnu peroksidaciju, sprječava gubitak fluidnosti bioloških membrana, promjene membranskoga potencijala i permeabilnosti prema $\mathrm{H}^{+} \mathrm{i}$ drugim ionima, te tako održava cjelovitost stanica.

\section{Antialergijski učinak matične mliječi}

Na modelu miša potvrđen je i antialergijski učinak matične mliječi (24). Ta se značajka pripisuje glikoproteinu mase $75 \mathrm{kDa}$, nazvanom glavni protein MM 3 (engl. major rojal jelly protein 3; MRJP3) koji inhibira proizvodnju IL-4 u stimuliranim stanicama slezene miševa imuniziranih ovalbuminom. MRJP3 inhibira ne samo IL-4, koji je ključan u prekapčanju teškog lanca IgE, te IL-2 i IFN- $\gamma$ odveden od stanica Tnego i proliferaciju stanica T. Snažni imunoregulatorni učinak tog proteina, posebice u inhibiciji razine $\operatorname{IgE} \mathrm{i}$ IgG1 imuniziranih miševa, mogao bi biti od kliničkog značaja u dizajniranju antialergičnih peptida. Oka i sur. (56) smatraju da je supresija alergijske reakcije s matičnom mliječi udružena s očuvanjem funkcije makrofaga i poboljšanjem Th1/Th2 odgovora. Ti su autori na DNP-KLH (engl. 2, 4-dinitrophenylated keyhole limpet hemocyanin) imuniziranom mišu potvrdili da matična mliječ čuva razinu GSH u makrofagima i povećava proizvodnju IL-12 i NO, a smanjuje proizvodnju prostaglandina E2 u makrofagnim stanicama. Zaključili su da matična mliječ suprimira antigen specifičnu proizvodnju $\operatorname{IgE}$ i oslobađanje histamina iz mastocita, čuva funkciju makrofaga te poboljšava Th1/Th2 stanični odgovor u DNP-KLH miševa. Povećanje razine GSH pomoću matične mliječi u makrofagima ključno je za povećanje IL-12 te usmjeravanje Th1 odgovora, a tome pogoduje i smanjenje razine prostaglandina E2; povećanje razine prostaglandina E2 suprimira Th1 odgovor i povećava razinu IgE. Nadalje, degranulacija mastocita smanjena je povećanjem razine NO iz makrofaga. Sve navedene odrednice pokazatelj su da matična mliječ može zaštititi od alergije ili ublažiti alergijske simptome te da inhibira razvoj kožnih lezija sličnih atopijskom dermatitisu (57).

\section{Estrogenski učinak matične mliječi}

Mishima i sur. (19) pokazali su da matična mliječ ima slab estrogenski učinak zbog kompeticije s $17 \beta$ estradiolom za vezno mjesto na $\alpha$ i $\beta$ estrogenski receptor ljudi. Obrada MCF-7 stanica s matičnom mliječi pojačava njihovu proliferaciju, a prateća obrada s $1 \mu \mathrm{mol} \mathrm{L} \mathrm{L}^{-1}$ tamoksifena (kemoterapeutik antagonist estrogenskoga receptora) taj učinak dokida. Nadalje, potkožna injekcija matične mliječi ponovo uspostavlja ekspresiju gena za krvožilni endotelijalni čimbenik rasta u ovarioktomiziranih miševa. Budući da estrogen ima ključnu ulogu u metabolizmu kosti, posebice u žena, nedostatak istoga glavni je čimbenik gubljenja koštane mase i razvoja osteoporoze u postmenopauzi. Uporaba fitoestrogena u prehrani značajna je opcija u sprječavanju osteoporeze. U in vitro istraživanjima uporabom mišje osteoblastične linije MC3T3-E1 pokazano je da genistein i daidzein povećavaju aktivnost alkalne fosfataze i pojačavaju mineralizaciju, vjerojatno kroz njihov estrogenski potencijal. Obrada stanica MC3T3-E1 s matičnom mliječi stimulira njihovu proliferaciju, proizvodnju kolagena tipa I i druge aktivnosti za formiranje kosti, djelujući na osteoblaste. Oralna primjena matične mliječi kod miševa tijekom devet tjedana povećala je težinu i sadržaj kosti tibije te prouzročila značajne promjene u ekspresiji gena koji se odnose na formiranje izvanstaničnog matriksa. Ista učinkovitost matične mliječi pokazala se i na štakorskome modelu, što potvrđuje da kao dodatak prehrani može biti nova alternativa u prevenciji osteoporoze $(20,58)$.

Husein i Kridli (59) te Huseini i Haddad (60) potvrdili su učinak matične mliječi na reproduktivnu sposobnost ovaca. Združena s progesteronom, matična mliječ može poboljšati reproduktivni odgovor u ovaca ubrzavanjem ovulacije, a utvrđen je i povećan rast folikula te lučenje estradiola.

\section{Antimikrobna aktivnost}

Upravo zbog niza problema vezanih za otpornost (rezistenciju) mikroorganizama na antibiotike koji su danas u uporabi, javlja se potreba za istraživanjem nove klase antibiotika s mehanizmima djelovanja na koje se ne bi razvila otpornost. U ovom su desetljeću plijesni i bakterije bili izvorište novih antibiotika, a kukci su tek nedavno postali zanimljivi istraživačima. Naime, oni nemaju limfocitni imunosni sustav, ali mogu uspješno odstraniti bakterije (61) i čak steći prijenosnu imunost, što upućuje na postojanje vrlo snažnih antimikrobnih tvari u kukcima. Osim kutikule kao fizičke zapreke, kukci imaju urođeni humoralni i stanični obrambeni sustav, temeljen na tkivima i hemocitima. Masno tkivo i stanice kukaca stvaraju brojne antimikrobne peptide, koji su sadržani u njihovoj hemolimfi. Ti peptidi djeluju na bakterije kroz nekoliko mehanizama: i) stvaraju peptidne monomere 
koji se udružuju i formiraju velike transmembranske kanale na bakterijskoj stijenci, ii) peptidi koji djeluju poput detergenta i razaraju bakterijsku staničnu stijenku. Peptidi se mogu svrstati prema spektru djelovanja u tri skupine: i) peptide aktivne protiv bakterija, ali ne protiv normalnih stanica sisavaca i gljiva (selektivni peptidi), ii) peptide aktivne protiv bakterija, ali i protiv normalnih stanica sisavaca, potencijalno aktivne i protiv gljiva, iii) peptide aktivne isključivo protiv gljiva, ali ne protiv bakterija i normalnih stanica sisavaca (62). Antibakterijska aktivnost pripisuje se proteinu mase $5,5 \mathrm{kDa}$ rojalizinu i trans-10-hidroksi-2-decenskoj kiselini, koji imaju učinak na gram-pozitivne i gram-negativne bakterijske vrste $(63,64)$. Te dvije antibakterijske sastavnice odgovorne su i za same pčele. Fontana i sur. (6) izolirali su iz matične mliječi četiri antibakterijska peptida (engl. Jelleine-I-IV) uporabom obrnuto-faznog HPLCa. U usporedbi s Jelleine-IV, Jelleine-I-III pokazuju isključivo antimikrobno svojstvo protiv kvasca, grampozitivnih i gram-negativnih bakterijskih vrsta. Navedeni antimikrobni peptidi (Jelleine I-IV) ne pokazuju sličnost s drugim antimikrobnim peptidima, poput himenoptaecina, apidaecina, abaescina i rojalizina. Matična mliječ ubija praživotinju vrste Trypanosoma cruzi, njeno je djelovanje potvrđeno i kod dizenterične amebe te na virus gripe. Višekratno davanje malih doza matične mliječi povećava otpornost na stres u pokusnih životinja, a velike doze djeluju letalno. Dokazana su i antibakterijska i baktericidna svojstva (na vrste Bacillus alvei, Streptococcus haemolyticus B, Staphylococcus aureus, Proteus vulgaris, Micrococcus, Listeria monocytogenes). Baktericidno djelovanje izraženije je kod gram pozitivnih mikroorganizama, a učinak je malo slabiji kod gram negativnih mikroorganizama, i može se okarakterizirati kao bakteriostatski (Escherichia coli). Antibakterijska učinkovitost pripisuje se slobodnim masnim kiselinama (65).

\section{Učinkovitost matične mliječi u snižavanju krvnog tlaka i zaštiti krvožilnog sustava i srca}

Antihipertenzivnu osobitost matične mliječi in vitro istražili su Okuda i sur. (66) te su utvrdili da su trans-2-oktenoična kiselina i trans-10-hidroksi-2decenska kiselina uključene u kontrolu krvnog tlaka. U uvjetima in vivo taj je hipotenzivni učinak nezasićenih masnih kiselina upitan zbog njihove nestabilnosti u probavnom sustavu. Matsui i sur. (67) objasnili su fiziološku funkciju matične mliječi na spontano hipertenzivnim štakorima. Matična mliječ sadrži proteine koji su dobro izvorište inhibitora angiotenzin-I-konvertirajućih peptida (engl. angiotensin I-converting enzyme; ACE), a nastaju enzimskom hidrolizom u probavnom sustavu. Krvni tlak $u$ organizmu regulira renin-angiotenzinski sustav, koji ima važnu fiziološku ulogu u cirkulaciji i/ili lokalnim organima. ACE inhibitorni peptidi, primjerice IY, VY i IVY u proteazama obrađenoj matičnoj mliječi otporni su na želučano-crijevne proteaze. Ti peptidi u krvnim žilama mogu regulirati lučenje drugih aktivnih tvari na tlak, primjerice $\mathrm{NO}-\mathrm{a}$, endotelina ili prostaglandina. Isti antihipertenzivni učinak peptida matične mliječi pokazali su i Tokunaga i sur. (68) na spontano hipertenzivnim štakorima, što potvrđuje da matična mliječ može biti funkcionalna hrana u poboljšanju krvnog tlaka ljudi s povišenim krvnim tlakom (hipertenzijom). Prema autorima (69-71) primjena hidrolizirane matične mliječi smanjuje visoku razinu kolesterola i povećava razinu hemoglobina u ljudi te poboljšava homeostazu organizma.

Primjena matične mliječi dovodi do sniženja razine kolesterola u pokusnih životinja i ateroskleroze u ljudi (69-71). Značajno je djelovala na metabolizam lipida u štakora i sprječila aterosklerozu u zeca koji je bio hranjen namirnicama bogatima kolesterolom. Povrh toga, oralna ili injekcijska primjena matične mliječi značajno snižava razinu serumskih lipida i kolesterola $\mathrm{u}$ aterosklerotskih pacijenata $\mathrm{s}$ umjereno visokom razinom kolesterola. Istražujući učinak matične mliječi na serumske lipide kod ljudi, Vitek (72) je pokazao da ona snižava ukupne lipide (oko $10 \%$ ) u serumu i jetrima, ali i razinu kolesterola (za $14 \%$ ) ako se primjenjuje redovito u dozi od $5 \mathrm{mg}$ do $100 \mathrm{mg}$ na dan najmanje 2-3 mjeseca. Visoka razina kolesterola u krvi rizični je čimbenik za bolesti srca i krvožilnog sustava kao što su ateroskleroza, visoki tlak, srčani udar, angina pektoris i druge srčane i krvožilne tegobe, čak za moždani udar i dijabetes.

Glavni lipidi plazme uključuju kolestrol, trigliceride i fosfolipide. Lipoproteini su makromolekularni kompleksi koji imaju važnu ulogu u prijenosu i metabolizmu lipida. Lipoprotein male gustoće (LDL, engl. Low Density Lipoproteins) glavni je prijenosnik kolesterola u krvotoku. Visoka razina kolesterola u serumu najčešće se odnosi na prekomjerno visoku razinu LDL kolesterola. Visoki LDL može biti posljedica njegova prevelikog stvaranja uslijed nedostatnog uklanjanja lipoproteina vrlo male gustoće (VLDL, engl. Very Low Density Lipoproteins), prekursora LDL-a putem jetara. LDL je proizvod 
nastao cijepanjem VLDL-a (veliki, srednji i mali VLDL). U plazmi su velike VLDL čestice eliminirane kao takve ili katabolizirane do malih VLDL kroz lipolizu triglicerida pomoću lipaza lipoproteina vezanih za endotel. Metabolizam VLDL pojavljuje se kao jedan od regulirajućih čimbenika koncentracije LDL kolesterola. Nadalje, VLDL vodi povećanju LDL-a, za koji je dokazano da ima aterogene značajke.

Guo i sur. (71) upućuju na to da unos matične mliječi kao dodatka prehrani smanjuje ukupnu razinu kolesterola i LDL-a, smanjenjem razine malog VLDLa. Nedavno je sugerirano da je mali VLDL snažni neovisni prediktor progresije bolesti i više izravno uključen u progresiju ateroskleroze od LDL-a, koji se tradicionalno smatra glavnim aterogenim lipoproteinom.

\section{Znanstvene tvrdnje o učinkovitosti matične mliječi na zdravlje ljudi prema PASSCLAIM-klasifikaciji}

Glavna je svrha PASSCLAIM-projekta (engl. Process for the Assessment of Scientific Support for Claims on Foods) definirati skup općeprimjenjivih kriterija za znanstveno obrazloženje zdravstvenih tvrdnji o učinkovitosti hrane. Ti se kriteriji smatraju znanstveno snažnim pokazateljima za procjenu kvalitete podataka dostavljenih u prilog tvrdnji o učinku hrane na zdravlje. Prema Uredbi Europske unije (EU) EC 1924/2006, za učinak matične mliječi mogu biti izvedene različite zdravstvene tvrdnje. Tvrdnje su svrstane prema PASSCLAIM-klasifikaciji (International Life Science Institute, ILSI) u sljedeća tematska područja:
1. Prehrana i kardiovaskularne bolesti

2. Zdravlje kostiju i osteoporoza

3. Fizička snaga i kondicija

4. Regulacija tjelesne težine, osjetljivost na inzulin i rizik od dijabetesa

5. Prehrana i rak

6. Mentalno stanje i učinkovitost

7. Zdravlje crijeva, probava i imunost

U skladu s podatcima iznesenima u ovom preglednom članku, mogu se izvesti sljedeće zdravstvene tvrdnje:

1. Prehrana i kardiovaskularne bolesti

Redovitom primjenom matične mliječi preventivno u dozi od $100 \mathrm{mg}$ do $200 \mathrm{mg}$ na dan može se poboljšati zdravlje kardiovaskularnog sustava, s obzirom na smanjenje kardiovasukularnih čimbenika rizika, masnoće i kolesterola u krvi. Prema autorima $(5,72$, 75) nakon 30 dana primjene matične mliječi treba napraviti stanku od 2 do 3 tjedna te započeti primjenu s nižim dozama.

2. Fizička snaga i kondicija

Uzimanjem matične mliječi može se poboljšati fizička snagu, kondicija i radna sposobnost, pogotovo u starijih osoba (engl. anti-age effect).

3. Prehrana i rak

Uzimanjem matične mliječi može se smanjiti rizik od raka.

4. Mentalno stanje i učinkovitost

Uzimanjem matične mliječi može se poboljšati mentalno stanje i fizička učinkovitost. Ti su učinci posebno značajni u starijih ljudi (engl. anti-age effect).

Tablica 1 Sastav svježe i liofilizirane matične mliječi

\begin{tabular}{lcc}
\hline Sastav & Svježa matična mliječ & Liofilizirana matična mliječ \\
\hline Voda / \% & 60 do 70 & $<5$ \\
\hline Lipidi / \% & 3 do 8 & 8 do 19 \\
\hline 10 -hidroksi-2-decenska kiselina (10-HDA) / \% & $>1,4$ & $>3,5$ \\
\hline Proteini / \% & 9 do 18 & 27 do 41 \\
\hline Fruktoza + glukoza+ sukroza / \% & 7 do 18 & - \\
\hline Fruktoza / \% & 3 do 13 & - \\
\hline Glukoza / \% & 4 do 8 & - \\
\hline Sukroza / \% & 0,5 do 2,0 & 2 do 5 \\
\hline Pepeo (suha tvar) / \% & 0,8 do 3,0 & 3,4 do 4,5 \\
\hline pH & 3,4 do 4,5 & - \\
\hline Kiselost / 0,1mol L ${ }^{-1} \mathrm{NaOH}\left(\mathrm{mL} \mathrm{g}^{-1}\right)$ & 3,0 do 6,0 & - \\
\hline Furozin / mg u100 g proteina & $<50$ & \\
\hline
\end{tabular}


Neki od navedenih bioloških učinaka vidljivi su u tablici 2 i tablici 3.

\section{Potreba standardizacije važnih biološki aktivnih sastavnica, utvrđivanja valjanosti i kakvoće pripravaka s matičnom mliječi}

Iako se matična mliječ primjenjuje od davnina, preporuka za njenu primjenu u humanoj terapiji datira od 1922. u Francuskoj, kada postaje predmet brojnih istraživanja. Primjena matične mliječi u medicini u mnogim zemljama diljem svijeta pod stalnom je kontrolom ministarstava zdravlja. U cilju sigurne primjene matične mliječi kao ljekovitoga pripravka, važno je sačuvati sastavnice odgovorne za blagotvoran učinak na zdravlje stalnom analizom kemijskoga sastava matične mliječi i kakvoće te osigurati sigurnu proizvodnju.

Od kraja 19. stoljeća do danas provedena su brojna istraživanja matične mliječi (98-100). Međutim, teško je spojiti podatke prikupljene od različitih autora zbog nedostatka homogenosti među uporabljenim materijalima, od različitih postupaka uzorkovanja i proizvodnih uvjeta. U dodatne čimbenike koji pridonose nehomogenosti podataka svrstavaju se i brojni eksperimentalni uvjeti, raznolikost analitičkih metoda te potreba za njihovom kontinuiranom provedbom.

Neophodno je poznavanje sastava matične mliječi kako bi se definirao standardni sastav, procijenila kakvoća komercijalnih proizvoda i otkrila prisutnost matične mliječi u drugim proizvodima koji je sadrže. Neke zemlje, poput Švicarske (100), Bugarske, Brazila i Urugvaja, definirale su nacionalne standarde za matičnu mliječ. Naime, postoje razlike u kakvoći matične mliječi, posebice sezonske i geografske, a neki smatraju da su neke promjene ovisne o vrsti pčela koje ih proizvode. Također, jasno treba navesti razlike između svježe matične mliječi i liofiliziranih uzoraka. Ukupni analitički podatci potvrdili su ne samo da izloženost temperaturi od $4{ }^{\circ} \mathrm{C}$ ne uzrokuje promjene u sastavu matične mliječi nego da njeno skladištenje u zamrznutom stanju sprečava razgradnju biološki aktivnih proteina, što upućuje na to da matičnu mliječ treba zamrznuti neposredno nakon skupljanja zbog očuvanja biološki aktivnih sastavnica (101). Prilično složen sastav matične mliječi čine različite bjelančevine, aminokiseline, organske kiseline, steroidi, esteri, fenoli, šećeri, minerali, elementi u tragovima i drugi sastojci (vidi gore navedene sastavnice svježe matične mliječi). Osim toga, njen sastav varira prema sezonskim i regionalnim uvjetima, a liofilizirani proizvod zbog visokog postotka vode sadrži $<5 \%$ vode, $(27$ do 41$) \%$ proteina, (22 do 31) \% ugljikohidrata i (15 do 30) \% masti. Neke bitne razlike u sastavnicama matične mliječi prikazane su u tablici 1 .

Nedavno je utvrđeno da cjelokupni proteini i peptidi daju antioksidativnu aktivnost matične mliječi (102-105). U nedavnom je istraživanju membranskom ultrafiltracijom i anionskom kromatografijom, gel filtracijom i reverzno-faznom visokotlačnom tekućinskom kromatografijom izolirano 29 antioksidativnih peptida iz hidrolizata matične mliječi. Antioksidativna svojstva tih peptida važna su zbog njihove sposobnosti da djeluju kao skupljači slobodnih radikala.

Glavnu hranidbenu vrijednost proteina hrane, pa tako i matične mliječi, određuje njihov aminokiselinski sastav. Stoga određivanje promjene sadržaja aminokiselina može biti učinkovit način za pristup kakvoći ovoga proizvoda. Aminokiseline prisutne u najvišim postotcima su prolin, lizin, glutaminska kiselina, $\beta$-alanin, fenilalanin, aspartat i serin (106). Međutim, u istim uzorcima koji su bili pohranjeni na sobnoj temperaturi sadržaj prolina i lizina pokazuje porast $\mathrm{u}$ prva tri mjeseca, a nakon 6 do 10 mjeseci njihova je razina bila niža od kontrolnih vrijednosti, što upućuje na proteolitičku enzimsku aktivnost $\mathrm{u}$ povoljnim temperaturnim uvjetima tijekom vremena.

Kvantitativni sastav slobodnih aminokiselina (FAA) i ukupnih aminokiselina (TAA) u uzorcima matične mliječi pohranjenima na različitoj temperaturi u različita razdoblja također bi trebalo istražiti. Rezultati su pokazali da je u svježoj matičnoj mliječi prosječna razina FAA $9,21 \mathrm{mg} \mathrm{g}^{-1}$, a razina TAA 111,27 $\mathrm{mg} \mathrm{g}^{-1}$. Glavne slobodne aminokiseline u matičnoj mliječi su prolin, glutamin, lizin, glutaminska kiselina, a najbrojnije TAA su asparagin, glutamin, leucin i lizin. Iako koncentracija većine FAA i TAA nije pokazala značajnu razliku tijekom skladištenja, sadržaj ukupnog metionina i slobodnoga glutamina znatno se smanjuje tijekom vremena i može biti parametar za kakvoću matične mliječi.

Osim toga, svježa matična mliječ sadrži masne kiseline (FA) i lipide (3 do 89) \%, a liofilizirana matična mliječ sadrži oko (15 do 30) \% masti.

Lipidni sastav matične mliječi čine masne kiseline (80 do 85) \%, fenoli, (4 do 10) \%, vosak (5 do 6) \%, steroidi (3 do 4$) \%$ i fosfolipidi $(0,4$ do 0,8$) \%$. FA dio sastoji se od $32 \%$ trans-10-hidroksi-2-decenske kiseline (10-HDA), $24 \%$ glukonske kiseline, $22 \%$ 10-hidroksidecenske kiseline (HDAA), $5 \%$ 
Tablica 2 Pregled bioloških i farmakoloških učinaka matične mliječi ostvarenih u pokusima na animalnim modelima i u kulturi stanica

\begin{tabular}{|c|c|}
\hline Učinak & Reference \\
\hline \multicolumn{2}{|l|}{ Antibakterijski, antivirusni, antiparazitski učinak } \\
\hline Antibakterijski & $6,61-65,82$ \\
\hline Protugljivični (fungicidni) & 6,80 \\
\hline Antivirusni & 43,80 \\
\hline Aktivnost protiv različitih parazita porodice Trypanosomidae & 6,65 \\
\hline \multicolumn{2}{|l|}{ Biostimulirajući i učinak protiv starenja } \\
\hline Estrogeni i gonadotropni učinci potvrđeni na stanicama i u štakoru & $19,20,58-60$ \\
\hline $\begin{array}{l}\text { Povećava rast i težinu pilića, purana, pataka, zečeva, zamoraca, ptica, svinja, teladi, hrčka, } \\
\text { miševa i štakora }\end{array}$ & 5,74 \\
\hline Protutumorski učinak, povećava aktivnost imunosnih stanica i otpornost na stres & $22,35-55$ \\
\hline Povećava reprodukcijski kapacitet u štakora i ovaca & 59,60 \\
\hline Povećava potrošnju kisika u tkivima in vitro, antihipoksički učinak & 49,66 \\
\hline Protiv neplodnosti muških kunića, poboljšava seksualnu učinkovitost u štakora i hrčka & 73 \\
\hline Produljenje života miševa i štakora & $41,42,45$ \\
\hline \multicolumn{2}{|l|}{ Imunomodulirani učinci: protutumorski, antialergijski i protuupalni } \\
\hline Imunostimulirajuća aktivnost u životinja ili u kulturama stanica, povećanje broja leukocita & $24,42,43,46-48$ \\
\hline Protutumorski učinci u kulturi stanica i životinjskim modelima (per os ili injekcije) & $35-41,43,45,50,51$ \\
\hline Sprečava autoimunost u miševa & 74 \\
\hline Protuupalni učinci (stanične kulture) & 23 \\
\hline \multicolumn{2}{|l|}{ Učinci na krvožilni sustav i srce } \\
\hline Smanjuje povećani krvni tlak, hipotenzivni učinak, vazodilatacija (na životinjama) & $66-71$ \\
\hline $\begin{array}{l}\text { Antiaterosklerozni učinak: smanjuje razinu kolesterola i triglicerida u krvi, povećava HDL, } \\
\text { snižava razinu fibrinogena u plazmi i trombozu }\end{array}$ & $68-71,74$ \\
\hline Kardio-zaštitni učinak (na životinjama), sprječava miokarditis & $68-71$ \\
\hline $\begin{array}{l}\text { Povećava razinu tiroksina, omjer albumina/globulina u krvi i smanjuje razine serumskih } \\
\text { proteina nakon oralne primjene u štakora }\end{array}$ & 5 \\
\hline \multicolumn{2}{|l|}{ Utjecaj na središnji i vegetativni živčani sustav } \\
\hline Djeluje na aktivnost središnjeg živčanog sustava, aktivira ga i štiti & $29-30$ \\
\hline Povećava diferencijaciju moždanih stanica & 30,31 \\
\hline $\begin{array}{l}\text { Povećava fosforilaciju središnjeg živčanog sustava povećanjem aktivnosti kolisteraza u } \\
\text { mozgu štakora }\end{array}$ & 29 \\
\hline Ima acetil-kolinu slične učinke na crijeva i na živčana vlakna glatkih mišića u dišnom sustavu & 25 \\
\hline Umirujući učinak (štakor) & 5,25 \\
\hline \multicolumn{2}{|l|}{ Antioksidativni, hepatoprotektivni $i$ zaštitni učinak od zračenja (radioprotektivni) } \\
\hline Antioksidativni učinak & $46-48,53-55,76$ \\
\hline Zaštita jetara u pokusima na životinjama & $52-55$ \\
\hline $\begin{array}{l}\text { Smanjuje stres i teratogenost, plućni edem i oštećenja jetara ili bubrega u štakora nakon } \\
\text { unosa mikotoksina }\end{array}$ & $53-55,77$ \\
\hline $\begin{array}{l}\text { Stimulira sintezu DNA u hepatocita i štiti stanice od apoptoze, mitogeni učinak, potiče } \\
\text { proliferaciju stanica i povećava proizvodnju albumina }\end{array}$ & $2,17,18$ \\
\hline Zaštitni učinak od zračenja u pokusima na životinjama & $46-49$ \\
\hline \multicolumn{2}{|l|}{ Drugi učinci } \\
\hline Sprječava osteoporozu u štakora i potiče formiranje kosti & 20,58 \\
\hline Zaštita kože: potiče izgradnju kolagena u kulturama stanica & 19 \\
\hline Hiperglikemijsko djelovanje, sprječava otpornost na inzulin, antidijabetički učinak & $32,33,34$ \\
\hline Smanjuje eksperimentalni kolitis u štakora & 77 \\
\hline Antialergijska aktivnost, smanjuje razvoj atopijskog dermatitisa poput kožnih lezija u & $24,56,57$ \\
\hline
\end{tabular}


Tablica 3 Medicinski učinci matične mliječi u ljudi

\begin{tabular}{lc}
\hline Uporaba & Reference \\
\hline Djeca & \\
\hline $\begin{array}{l}\text { U nedonoščadi ili nedostatnoj prehrani: poboljšanje općeg stanja, povećanje težine, apetita, } \\
\text { broja crvenih krvnih stanica i razine hemoglobina }\end{array}$ & $5,25,79,80$ \\
\hline Odrasli & \\
\hline Poboljšava opće stanje i oporavak starih ljudi od slabosti i problema u menopauzi & $73,74,78,82-84,86$ \\
\hline $\begin{array}{l}\text { Protiv stenokardije i nakon srčanog infarkta; arterioskleroze i ateroskleroze; hipertenzija, } \\
\text { hipotenzija }\end{array}$ & $72-74,86$ \\
\hline Protiv bolesti dišnog sustava, astme & 86 \\
\hline $\begin{array}{l}\text { Protiv bolesti oka, primjerice blepharitisa, konjuktivitisa i oštećenja rožnice, poremećene } \\
\text { cirkulacije u oku }\end{array}$ & 88,90 \\
\hline $\begin{array}{l}\text { Biostimulirajući učinak, poboljšava fizičku kondiciju i radnu sposobnosti te otpornost na } \\
\text { hipoksiju }\end{array}$ & 80,83 \\
\hline Poboljšava memoriju, neurovegetativnu aktivaciju & 83,86 \\
\hline Protiv dijabetesa tip 1 & $86,94-97$ \\
\hline Protiv raka & 78,90 \\
\hline Protiv ulkusa želuca i dvanaesnika, želučanih tegoba & 87 \\
\hline Pospješuje regeneraciju i zacjeljivanje rana kože & 91 \\
\hline Protiv degenerativnih promjena i reumatizma & 90 \\
\hline Protiv bradavica, akni, čireva, seboreje, neurodermatitisa & 92 \\
\hline Protiv bubrežne disfunkcije & 93 \\
\hline
\end{tabular}

dikarboksilne kiseline i od nekoliko drugih kiselina. 10-HDA i HDAA specifične su sastavnice matične mliječi (107). Osim što je najvažniji kriterij kakvoće, HDA može biti i pokazatelj da se radi o krivotvorini. Iz tog je razloga 10-HDA sadržaj prihvaćen kao biljeg za matičnu mliječ i koristi se za analizu njene kakvoće. Međutim, u literaturi su sastav i krajnje granice za razinu 10-HDA vrlo široke. Primjerice, Antinelli i sur. (108) pokazali su smanjenje 10-HDA od 0,4 \% i 0,6 \% u dvama uzorcima matične mliječi pohranjenima na sobnoj temperaturi tijekom 12 mjeseci. Štoviše, zbog svoje promjenjive vrijednosti u svježoj matičnoj mliječi, 10-HDA teško se može koristiti kao pokazatelj svježine. Rezultati HPLC analize i elektroforeze pokazali su da uzorci matične mliječi europskoga podrijetla sadrže manje količine 10-HDA, a to potvrđuje i mjerenje ukupnih lipida nakon ekstrakcije otapalom (109). Stoga se smatra da bi mjerenje ukupne razine masnih kiselina mogao biti bolji pokazatelj od određivanja prisutnosti same 10-HDA $(95,110$, 111).

Autentičnost proizvodnje matične mliječi može se odrediti ne samo mjerenjem omjera stabilnih izotopa elemenata $\mathrm{C}$ i N (112) i određivanjem sastava masnih kiselina u RJ $(95,113)$ nego i analizom šećera (114).

Zemljopisna autentičnost može se utvrditi i peludnom analizom $(115,116)$. Omjeri ${ }^{87} \mathrm{Sr} /{ }^{86} \mathrm{Sr}$ upućuju na zemljopisno podrijetlo uzoraka (112).
Količina peluda te vidljivog voska i ostataka ličinki treba biti minimalna (117). Za procjenu kvalitativnih i hranidbenih vrijednosti matične mliječi može poslužiti određivanje razine slobodnog i cjelokupnog triptofana (118).

Prema tome, ključni parametri u istraživanju kakvoće matične mliječi su njena organoleptička svojstva, fizikalno-kemijska svojstva i sastav, kako slijedi: a) sadržaj vode u suhom i zamrznutom uzorku matične mliječi; b) ukupna razina proteina i slobodnih aminokiselina; c) razina ugljikohidrata; d) razina lipida; ukupnih masnih kiselina i slobodnih kiselina; e) 10 HDA; f) minerali; g) kiselost; h) analiza sedimenta; i) furazin; j) moguća kontaminacija.

Za procjenu svježine matične mliječi ili njenih pripravka mogu se rabiti neke od sljedećih metoda: određivanje glukoza oksidaza, furozina ili aktivnosti superoksid dizmutaza (SOD). Određivanje glukoza oksidaza analitički je vrlo jednostavna metoda, primjenjiva u svim laboratorijima. Svakako treba istaknuti da najprije treba istražiti prirodnu varijabilnost tog enzima u svježem proizvodu (119). Marconi i sur. (120) smatraju da se kao biljeg za procjenu svježine matične mliječi može rabiti sadržaj furozina. Vrijednost furozina, proizvoda Maillardove reakcije, u svježim uzorcima matične mliječi izrazito je niska $(<10 \mathrm{mg} \mathrm{u} 100 \mathrm{~g}$ proteina) (121), ali se s vremenom te u odnosu na temperaturu povećava. Naime, sadržaj 
se može povećati na $500 \mathrm{mg} \mathrm{u} 100 \mathrm{~g}$ proteina nakon 18 mjeseci skladištenja pri sobnoj temperaturi i na 50 mg u 100 g na $4{ }^{\circ} \mathrm{C}$. Uzorci uzeti s polica trgovina pokazali su vrijednosti u rasponu od 40 do $100 \mathrm{mg} \mathrm{u}$ 100 g proteina. Nasuprot tome, liofilizirana matična mliječ ima snažnu tendenciju da pojačano formira furozin tijekom skladištenja (121). Osim toga za procjenu svježine matične mliječi korisno je mjeriti i aktivnost enzima SOD (122).

U liofiliziranim uzorcima skladištenjem na sobnoj temperaturi razina furozina može porasti na $500,8 \mathrm{mg}$ u 100 g proteina tijekom 10 mjeseci (121).

Na temelju navedenoga, pripravci koji sadržavaju matičnu mliječ moraju se pripremati uz strogo pridržavanje sanitarno-higijenskih uvjeta i mjera te pod nadzorom stručnjaka kako bi primjena matične mliječi mogla postići svoje djelotvorne učinke.

\section{Zaključne napomene}

Mogućnost uporabe matične mliječi temelji se na sljedećim biološkim osobitostima: biostimulativni učinak - sposobnost pojačavanja disanja tkiva, pojačava oksidativnu fosforilaciju, ubrzava izmjenu tvari, povećanje energije i izdržljivosti, stimulira parasimpatički centar vegetativnog sustava i pojačava izlučivanje adrealina iz nadbubrežne žlijezde, povećava otpornost na stres i bolesti, pomaže $u$ održavanju i jačanju kose, kožnog tonusa i noktiju, pomaže u regeneraciji stanica i tkiva, smanjuje razinu kolesterola, pozitivno djeluje na krvožilni sustav, stabilizira krvni tlak, poboljšava memoriju (acetil kolin neurotransmiter), stimulira imunosni sustav, potiče apetit, regulira probavu, održava ravnotežu hormona, olakšava menstrualne simptome, pomaže u liječenju impotencije i frigidnosti, otklanja slabost $i$ umor, pozitivno djeluje na artritis, anemiju, mišićnu distrofiju i Parkinsonovu bolest te djeluje antiupalno, antivirusno i antibiotički (vidi Tablicu 2 i Tablicu 3). No pokazalo se da matična mliječ može izazvati $i$ kontaktni dermatitis i anafilaksiju zbog prisutnosti brojnih proteina $(84,123,124)$ u pojedinih ljudi, što zahtijeva oprez prilikom njene uporabe. Matična mliječ može se ograničeno uzimati u bolestima kao što je bronhijalna astma u krizi (kap astrigent - ona može dovesti do bronhiektazije), Adisonova bolest, akutne zarazne i bolesti nadbubrežne žljezde te tumor u akutnoj fazi. Matičnu mliječ nije poželjno primjenjivati navečer jer često može prouzročiti različite nuspojave i nesanicu.

$\mathrm{Na}$ temelju navedenih značajki matične mliječi, nužno je napraviti izbor dobrih i pogodnih metoda koje bi bile ključne za njenu standardizaciju, posebice za razinu važnih biološki aktivnih sastavnica, valjanost i kakvoću proizvoda radi što bolje učinkovitosti pripravaka matične mliječi na ljudsko zdravlje i kvalitetu života. Spoznaje o razini glavnih bioloških sastavnica i njihovoj sezonskoj i geografskoj varijabilnosti, njihovoj promjenjivosti tijekom vremena i načinu pravilnog skladištenja te pronalazak sigurne terapeutske doze važne su u prevenciji i zaštiti od bolesti. Nadalje, spoznajom o ljekovitim osobitostima matične mliječi omogućit će se njihova veća primjena te potaknuti proizvodnja, što će dovesti do ekonomski isplativa pčelarenja. Na temelju promjena sastavnica matične mliječi tijekom vremena, različitog skladištenja, liofilizacije ili podrijetla, nužno je provesti njenu analizu i standardizaciju. A one se trebaju zasnivati na prikupljanju uzoraka matične mliječi s različitih hrvatskih područja te na analizi ključnih sastavnica, primjerice na a) sadržaju vode u suhom i zamrznutom uzorku, b) ukupnoj razini proteina i slobodnih aminokiselina, c) razini ugljikohidrata, d) razini lipida, ukupnih masnih kiselina i slobodnih kiselina, e)10 HDA, f) minerala, g) kiselosti, h) analizi sedimenta, i) furazina te $j$ ) moguće kontaminacije.

\section{LITERATURA}

1. Chandrasekara A, Shahidi F. Bioactivities and antiradical properties of millet grains and hulls. J Agric Food Chem 2011;59:9563-71. doi: 10.1021/jf201849d

2. Kamakura M. Royalactin induces queen differentiation in honeybees. Nature 2011;473:478-83. doi: 10.1038/ nature 10093

3. Vecchi MA, Sabatini AG, Grazia L, Tini V, Zambonelli C. Il contenuto in vitamine come possibile elemento di caratterizzazione della gelatina reale [The content in vitamins as a possible element of characterization of the royal jelly, in Italian]. Apicoltura 1988;4:139-46.

4. Tamura S, Kono T, Harada C, Yamaguchi K, Moriyama T. Estimation and characterisation of major royaljelly proteins obtained from the honeybee Apis merifera. Food Chem 2009;114:1491-7. doi: 10.1016/j.foodchem.2008.11.058

5. Bogdanov S. Royal Jelly, Bee Brood: Composition, Health, Medicine: A Review [pristup 28. lipnja 2013.]. Dostupno na http://www.bee-hexagon.net/files/file/fileE/Health/ RJBookReview.pdf

6. Fontana R, Mendes MA, De Souza, BM, Konno K, César LM, Malaspina O, Palma MS. Jelleines: a family of antimicrobial peptides from the Royal Jelly of honeybees (Apis mellifera). Peptides 2004;25:919-28. doi: 10.1016/j. peptides.2004.03.016

7. Sabatini AG, Marcazzan G, Caboni MF, Bogdanov S, Almeida-Muradian LB. Quality and standardisation of royal jelly. JAAS 2009;1:1-6. doi: 10.3896/IBRA.4.01.1.04 
8. Schmitzová J, Klaudiny J, Albert S, Schröder W, Schreckengost W, Hanes J, Júdová J, Simúth J. A family of major royal jelly proteins of the honeybee Apis mellifera L. Cell Mol Life Sci 1998;54:1020-30. PMID: 9791542

9. Simúth J, Bíliková K, Kovácová E, Kuzmová Z, Schröder W. Immunochemical approach to detection of adulteration in honey: physiologically active royal jelly protein stimulating TNF-alpha release is a regular component of honey. J Agric Food Chem 2004;52:2154-8. doi: 10.1021/jf034777y

10. Albert S, Klaudiny J. The MRJP/YELLOW protein family of Apis mellifera: identification of new members in the EST library. J Insect Physiol 2004;50:51-9. PMID: 15037093

11. Drapeau MD, Albert S, Kucharski R, Prusko C, Maleszka R. Evolution of the Yellow/Major Royal Jelly Protein family and the emergence of social behavior in honey bees. Genome Res 2006;16:1385-94. doi: 10.1101/gr.5012006

12. Schönleben S, Sickmann A, Mueller MJ, Reinders J. Proteome analysis of Apis mellifera royal jelly. Anal Bioanal Chem 2007;389:1087-93. doi: 10.1007/s00216-007-14982

13. Bíliková K, Simúth J. New criterion for evaluation of honey: quantification of royal jelly protein apalbumin 1 in honey by ELISA. J Agric Food Chem 2010;58:8776-81. doi: 10.1021/ jf101583s

14. Kimura M, Kimura Y, Tsumura K, Okihara K, Sugimoto H, Yamada H, Yonekura M. 350-kDa royal jelly glycoprotein (apisin), which stimulates proliferation of human monocytes, bears the beta1-3galactosylated N-glycan: analysis of the N-glycosylation site. Biosci Biotechnol Biochem 2003;67:2055-8. PMID: 14520005

15. Li J, Wang T, Zhang Z, Pan Y. Proteomic analysis of royal jelly from three strains of western honeybees (Apis mellifera). J Agric Food Chem 2007;55:8411-22. doi: 10.1021/ jf0717440

16. Ramadan MF, Al-Ghamdi A. Bioactive compounds and health-promoting properties of royal jelly: A review. J Funct Foods 2012;4:39-52. doi: 10.1016/j.jff.2011.12.007

17. Kamakura M, Suenobu N, Fukushima M. Fifty-seven-kDa protein in royal jelly enhances proliferation of primary cultured rat hepatocytes and increases albumin production in the absence of serum. Biochem Biophys Res Commun 2001;282:865-74. doi: 10.1006/bbrc.2001.4656

18. Kamakura M, Moriyama T, Sakaki T. Changes in hepatic gene expression associated with the hypocholesterolaemic activity of royal jelly. J Pharm Pharmacol 2006;58:1683-9. PMID: 17331334

19. Mishima S, Suzuki KM, Isohama Y, Kuratsu N, Araki Y, Inoue M, Miyata T. Royal jelly has estrogenic effects in vitro and in vivo. J Ethnopharmacol 2005;101:215-20. doi: 10.1016/j.jep.2005.04.012

20. Narita Y, Ohta S, Suzuki KM, Nemoto T, Abe K, Mishima S. Effects of long-term administration of royal jelly on pituitary weight and gene expression in middle-aged female rats. Biosci Biotechnol Biochem 2009;73:431-3. PMID 19202272

21. Watanabe K, Shinmoto H, Kobori M, Tsushida T, Shinohara K, Kanaeda J, Yonekura M. Stimulation of cell growth in the U-937 human myeloid cell line by honey royal jelly protein. Cytotechnology 1998;26:23-7. doi: 10.1023/ A:1007928408128

22. Nakaya M, Onda H, Sasaki K, Yukiyoshi A, Tachibana H, Yamada K. Effect of royal jelly on bisphenol A-induced proliferation of human breast cancer cells. Biosci Biotechnol Biochem 2007;71:253-5. PMID: 17213647

23. Kohno K, Okamoto I, Sano O, Arai N, Iwaki K, Ikeda M, Kurimoto M. Royal jelly inhibits the production of proinflammatory cytokines by activated macrophages. Biosci Biotechnol Biochem 2004;68:138-45. PMID: 14745176

24. Okamoto I, Taniguchi Y, Kunikata T, Kohno K, Iwaki K, Ikeda M, Kurimoto M. Major royal jelly protein 3 modulates immune responses in vitro and in vivo. Life Sci 2003;73:202945. doi: 10.1016/S0024-3205(03)00562-9

25. Salazar-Olivo LA, Paz-González V. Screening of biological activities present in honeybee (Apis mellifera) royal jelly. Toxicol In Vitro 2005;19:645-51. doi: 10.1016/j. tiv.2005.03.001

26. Inoue $\mathrm{S}$, Koya-Miyata $\mathrm{S}$, Ushio $\mathrm{S}$, Iwaki $\mathrm{K}$, Ikeda $\mathrm{M}$, Kurimoto M. Royal Jelly prolongs the life span of $\mathrm{C} 3 \mathrm{H} / \mathrm{HeJ}$ mice: correlation with reduced DNA damage. Exp Gerontol 2003;38:965-9. PMID: 12954483

27. Oršolić N. Bašić I. Honey bee products and their polyphenolic compounds in treatment of diabetes. U: Govil JN, Singh VK, Bhardwaj R, urednici. Phytopharmacology and Therapetutic Values IV. Rec Prog Med Plants 2008;22:455-553.

28. Koya-Miyata S, Okamoto I, Ushio S, Iwaki K, Ikeda M, Kurimoto M. Identification of a collagen productionpromoting factor from an extract of royal jelly and its possible mechanism. Biosci Biotechnol Biochem 2004;68:767-73. PMID: 15118301

29. Hashimoto M, Kanda M, Ikeno K, Hayashi Y, Nakamura T, Ogawa Y, Fukumitsu H, Nomoto H, Furukawa S. Oral administration of royal jelly facilitates mRNA expression of glial cell line-derived neurotrophic factor and neurofilament $\mathrm{H}$ in the hippocampus of the adult mouse brain. Biosci Biotechnol Biochem 2005;69:800-5. PMID: 15849420

30. Hattori N, Nomoto H, Fukumitsu H, Mishima S, Furukawa S. Royal jelly and its unique fatty acid, 10-hydroxy-trans-2decenoic acid, promote neurogenesis by neural stem/ progenitor cells in vitro. Biomed Res 2007;28:261-6. PMID: 18000339

31. Hattori N, Ohta S, Sakamoto T, Mishima S, Furukawa S, Royal jelly facilitates restoration of the cognitive ability in trimethyltin-intoxicated mice. Evid Based Complement Alternat Med 2011;2011:165968. doi: 10.1093/ecam/ nep029

32. Fujii A, Kobayashi S, Kuboyama N, Furukawa Y, Kaneko Y, Ishihama S, Yamamoto H, Tamura T. Augmentation of wound healing by royal jelly (RJ) in streptozotocin-diabetic rats. Jpn J Pharmacol 1990;53:331-7. PMID: 2391765

33. Erski-Biljić M, Biljić Erski A, Rajić Savić N. Matični mleč - kraljevski gel (Apiterapija, knjiga 2.). Beograd: Grafos; 2003.

34. Nomura M, Maruo N, Zamami Y, Takatori S, Doi S, Kawasaki H. [Effect of long-term treatment with royal jelly on insulin resistance in Otsuka Long-Evans Tokushima Fatty (OLETF) rats, in Japanese]. Yakugaku Zasshi 2007;127:1877-82. PMID: 17978564

35. Tamura T, Fujii A, Kuboyama N. [Antitumor effects of royal jelly, in Japanese]. Nippon Yakurigaku Zasshi 1987;89:73-80. PMID: 3570105

36. Tamura T, Fujii A, Kuboyama N. Effects of royal jelly on experimental transplantable tumours. U: The XXX ${ }^{\text {th }}$ International Apicultural Congress; 10.-16. listopada 1985. 
Nagoya, Japan. Bucharest: Apimondia Publishing House; 1985. str. 474-7.

37. Townsend GF, Morgan JF, Hazlett B. Activity of 10hydroxydecenoic acid from royal jelly against experimental leukaemia and ascitic tumors. Nature 1959;183:1270-1. doi: 10.1038/1831270a0

38. Townsend GF, Morgan JF, Hazlett B, Hazlett B, Morton H, Shuel RW. Studies on the in vitro antitumor activity of fatty acid and 10-hydroxy-2-decenoic acid from royal jelly. Cancer Res 1960;20:503-10

39. Oršolić N, Knežević A, Šver L, Terzić S, Hackenberger BK, Bašić I. Influence of honey bee products on transplantable murine tumors. Vet Comp Oncol 2003;1:216-26. doi: 10.1111/j.1476-5810.2003.00029.x

40. Oršolić N, Sacases F, Percie Du Sert P, Bašić I. Antimetastatic ability of honey bee products. Period biol 2007;109:17380.

41. Oršolić N, Terzić S, Šver L, Bašić I. Honey-bee products in preventive and/or terapy of murine transplantable tumours. J Sci Food Agric 2005;85:363-70. doi: 10.1002/jsfa.2041

42. Šver L, Oršolić N, Tadić Z, Njari B, Valpotić I, Bašić I. A royal jelly a new potential immunomodulator in rats and mice. Comp Immun Microbiol Infect Dis 1996;19:31-8. PMID: 8654043

43. Vucevic D, Melliou E, Vasilijic S, Gasic S, Ivanovski P, Chinou I, Colic M. Fatty acids isolated from royal jelly modulate dendritic cell-mediated immune response in vitro. Int Immunopharmacol 2007;7:1211-20. doi: 10.1016/j. intimp.2007.05.005

44. Bincoletto C, Eberlin S, Figueiredo CA, Luengo MB, Queiroz ML. Effects produced by Royal Jelly on haematopoiesis: relation with host resistance against Ehrlich ascites tumour challenge. Int Immunopharmacol 2005;5:679-88. doi: 10.1016/j.intimp.2004.11.015

45. Allavena P, Mantovani A. Immunology in the clinic review series; focus on cancer: tumour-associated macrophages: undisputed stars of the inflammatory tumour microenvironment. Clin Exp Immunol. 2012;167:195-205.

46. Emori Y, Oka H, Kobayashi N, Ohya O, Tamaki H, Hayashi $\mathrm{H}$, Nomoto K. [Protective effect of royal jelly on immune dysfunction in aged mice, in Japanese]. Biotherapy (Tokyo) 1999;13:281-7

47. Emori Y, Oka H, Ohya O, Tamaki H, Hayashi H, Nomoto K. [The protective effect of royal jelly against the hemopoiesis dysfunction in X-irradiated mice, in Japanese]. Biotherapy (Tokyo) 1998;12:313-9.

48. Emori Y, Oka H, Ohya O, Tamaki H, Hayashi H, Nomoto K. [The protective effect of royal jelly on cecal ligation and puncture-induced sepsis in X-irradiated mice, in Japanese]. Biotherapy (Tokyo) 1998;12:1143-8.

49. Krylov V, Koryagin AS, Nikolaeva AA, Sinelschikov AD, Ovoschnikova LV. Experiments on therapeutic effects of preparations of beekeeping products on radiation illnesses. Mellifera 2002:2:58-61.

50. Gore AC, editor. Endocrine-Disrupting Chemicals: From Basic Research to Clinical Practice. Totowa (NJ): Humana Press Inc.; 2007.

51. O'Connor JC, Chapin RE. Critical evaluation of observed adverse effects of endocrine active substances on reproduction and development, the immune system, and the nervous system. Pure Appl Chem 2003;75:2099-123. doi: 10.1351/ pac200375112099
52. Karadeniz A, Simsek N, Karakus E, Yildirim S, Kara A, Can I, Kisa F, Emre H, Turkeli M. Royal jelly modulates oxidative stress and apoptosis in liver and kidneys of rats treated with cisplatin. Oxid Med Cell Longev 2011;2011:981793, doi:10.1155/2011/981793

53. Cemek M, Aymelek F, Büyükokuroĝlu ME, Karaca T, Büyükben A, Yilmaz F. Protective potential of Royal Jelly against carbon tetrachloride induced-toxicity and changes in the serum sialic acid levels. Food Chem Toxicol 2010;48:282732. doi: $10.1016 /$ j.fct.2010.07.013

54. Kanbur M, Eraslan G, Beyaz L, Silici S, Liman BC, Altinordulu S, Atasever A. The effects of royal jelly on liver damage induced by paracetamol in mice. Exp Toxicol Pathol 2009;61:123-32. doi: 10.1016/j.etp.2008.06.003

55. Çavuşoulu K, Yapar K, Yalçin E. Royal jelly (honey bee) is a potential antioxidant against cadmium-induced genotoxicity and oxidative stress in albino mice. J Med Food 2009; 12:128692. doi: 10.1089/jmf.2008.0203

56. Oka H, Emori Y, Kobayashi N, Hayashi Y, Nomoto K. Suppression of allergic reactions by royal jelly in association with the restoration of macrophage function and the improvement of Th1/Th2 cell responses. Int Immunopharmacol 2001;1:521-32. PMID: 11367535

57. Taniguchi $Y$, Kohno K, Inoue S, Koya-Miyata S, Okamoto I, Arai N, Iwaki K, Ikeda M, Kurimoto M. Oral administration of royal jelly inhibits the development of atopic dermatitislike skin lesions in NC/Nga mice. Int Immunopharmacol 2003;3:1313-24. doi: 10.1016/S1567-5769(03)00132-2

58. Hidaka S, Okamoto Y, Uchiyama S, Nakatsuma A, Hashimoto K, Ohnishi ST, Yamaguchi M. Royal jelly prevents osteoporosis in rats: beneficial effects in ovariectomy model and in bone tissue culture model. Evid Based Complement Alternat Med 2006;3:339-48. doi: 10.1093/ecam/nel019

59. Husein MQ, Kridli RT. Reproductive responses following royal jelly treatment administered orally or intramuscularly into progesterone-treated Awassi ewes. Anim Reprod Sci 2002;74:45-53. PMID: 12379374

60. Husein MQ, Haddad SG. A new approach to enhance reproductive performance in sheep using royal jelly in comparison with equine chorionic gonadotropin. Anim Reprod Sci 2006;93:24-33. PMID: 16055281

61. Boman HG. Peptide antibiotics: holy or heretic grails of innate immunity? Scand J Immunol 1996;43:475-82. PMID: 8633204

62. Papo N, Shai Y. Effect of drastic sequence alteration and D-amino acid incorporation on the membrane binding behavior of lytic peptides. Biochemistry 2004;43:6393-403. doi: 10.1021/bi049944h

63. Fujiwara S, Imai J, Fujiwara M, Yaeshima T, Kawashima $\mathrm{T}$, Kobayashi K. A potent antibacterial protein in royal jelly. Purification and determination of the primary structure of royalisin. J Biol Chem 1990;265:11333-7. PMID: 2358464

64. Genç M, Aslan A. Determination of trans-10-hydroxy-2decenoic acid content in pure royal jelly and royal jelly products by column liquid chromatography. J Chromatogr A 1999;839:265-8. PMID: 10327631

65. Boukraâ L, Meslem A, Benhanifia M, Hammoudi SM. Synergistic effect of starch and royal jelly against Staphylococcus aureus and Escherichia coli. J Altern Complement Med 2009;15:755-7. doi: 10.1089/ acm.2008.0483 
66. Okuda H, Kameda K, Morimoto C, Matsuura Y, Chikaki M, Ming J. Studies on insulinlike substances in royal jelly and other substances in royal jelly which inhibit angiotensinconverting enzyme. Honeybee Sci 1998;19:9-14.

67. Matsui T, Yukiyoshi A, Doi S, Sugimoto H, Yamada H, Matsumoto K. Gastrointestinal enzyme production of bioactive peptides from royal jelly protein and their antihypertensive ability in SHR. J Nutr Biochem 2002;13:806. PMID: 11834223

68. Tokunaga KH, Yoshida C, Suzuki KM, Maruyama H, Futamura Y, Araki Y, Mishima S. Antihypertensive effect of peptides from royal jelly in spontaneously hypertensive rats. Biol Pharm Bull 2004;27:189-92. PMID: 14758031

69. Takaki-Doi S, Hashimoto K, Yamamura M, Kamei C. Antihypertensive activities of royal jelly protein hydrolysate and its fractions in spontaneously hypertensive rats. Acta Med Okayama 2009;63:57-64. PMID: 19247423

70. Morita H, Ikeda T, Kajita K, Fujioka K, Mori I, Okada H, Uno Y, Ishizuka T. Effect of royal jelly ingestion for six months on healthy volunteers. Nutr J 2012;11:77. doi:10.1186/1475-2891-11-77

71. Guo H, Saiga A, Sato M, Miyazawa I, Shibata M, Takahata Y, Morimatsu F. Royal jelly supplementation improves lipoprotein metabolism in humans. J Nutr Sci Vitaminol (Tokyo) 2007;53:345-8. PMID: 17934240

72. Vittek J. Effect of royal jelly on serum lipids in experimental animals and humans with atherosclerosis. Experientia 1995;51:927-35. doi: 10.1007/BF01921742

73. Elnagar S. Royal jelly counteracts bucks' "summer infertility”. Anim Repr Sci 2010;121:174-80. doi: 10.1016/ j.anireprosci.2010.05.008

74. Mannoor MK, Shimabukuro I, Tsukamotoa M, Watanabe H, Yamaguchi K. Honeybee royal jelly inhibits autoimmunity in SLE-prone NZB x NZW F1 mice. Lupus 2009;1:44-52. doi: $10.1177 / 0961203308094765$

75. Poplawsky A. Food for thought: royal jelly for the people. The Central Sulcus 2008;4:3-4.

76. Abdel-Wahhab MA, El-Nekeety AA, Abbas NF, El-Kholy W, Amra HA, Ebaid A. Efficacy of royal jelly against fumonisin-induced oxidative stress in rats. Toxicol Lett 2006;164(Supplement):S229-30.

77. Karaca T, Bayiroglu F, Yoruk M, Kaya MS, Uslu S, Comba B, Mis L. Effect of royaljelly on experimental colitis induced by acetic acid and alteration of mast cell distribution in the colon of rats. Eur J Histochem 2010;54:e35. PMID: 21263740

78. Sugiyama T, Takahashi K, Mori H. Royal jelly acid, 10hydroxy-trans-2-decenoic acid, as a modulator of the innate immune responses. Endocr Metab Immune Disord Drug Targets 2012;12:368-76. PMID: 23061418

79. King DS, Baskerville R, Hellsten Y, Senchina DS, Burke LM, Stear SJ, Castell LM. A-Z of nutritional supplements: dietary supplements, sports nutrition foods and ergogenic aids for health and performance-Part 34. Br J Sports Med 2012;46:689-90. doi: 10.1136/bjsports-2012-091314

80. Cherniack EP. Bugs as drugs, Part 1: Insects: the "new" alternative medicine for the $21^{\text {st }}$ century? Altern Med Rev 2010;15:124-35. PMID: 20806997

81. Boukraâ L, Sulaiman SA. Rediscovering the antibiotics of the hive. Recent Pat Antiinfect Drug Discov 2009;4:206-13 PMID: 19673699
82. Viuda-Martos M, Ruiz-Navajas Y, Fernández-López J, PérezAlvarez JA. Functional properties of honey, propolis, and royal jelly. J Food Sci 2008;73:R117-24. doi: 10.1111/j.17503841.2008.00966.x

83. Miyata T. Pharmacological basis of traditional medicines and health supplements as curatives. J Pharmacol Sci 2007;103:127-31. PMID: 17287592

84. Dzopalic T, Vucevic D, Tomic S, Djokic J, Chinou I, Colic M. 3,10-Dihydroxy-decanoicacid, isolated from royal jelly, stimulates Th1 polarising capability of human monocytederived dendritic cells. Food Chem 2011;126:1211-7. doi: 10.1016/j.foodchem.2010.12.004

85. Takahama H, Shimazu T. Food-induced anaphylaxis caused by ingestion of royal jelly. J Dermatol 2006;33:424-6. PMID: 16700835

86. Shkenderov S, Ivanov T. Pcelni Produkti [The Bee Products, in Bulgarian]. Zemizdat(Abstract in Honey bibliography)1983. $1-238$.

87. Ghosh S, Playford RJ. Bioactive natural compounds for the treatment of gastrointestinal disorders. Clin Sci (London) 2003;104:547-56. PMID: 12641494

88. Mozherenkov VP, Miniaeva TG. [The use of products from bee raising in ophthalmology and otorhinolaryngology, in Russian]. Med Sestra 1991;50:47-51. PMID: 1803198

89. Popescu MP, Alexandra D, Popescu M. [Royal jelly and its use in ophthalmology, in Romanian]. Rev Chir Oncol Radiol O R L Oftalmol Stomatol Ser Oftalmol 1987;31:53-6. PMID: 2955470

90. Yang XY, Yang DS, Wei Z, Wang JM, Li CY, Ye H, Lei KF, Chen XF, Shen NH, Jin LQ, Wang JG. 10-Hydroxy-2decenoic acid from royal jelly: A potential medicine for RA. J Ethnopharmacol 2010;128:314-21. doi: 10.1016/j. jep.2010.01.055

91. Rustogi R, Mill J, Fraser JF, Kimble RM. The use of Acticoat $^{\mathrm{TM}}$ in neonatal burns. Burns 2005;31:878-82. doi: 10.1016/j.burns.2005.04.030

92. Hayashi T, Takamatsu N, Nakashima T, Arita T. Immunological characterization of honey proteins and identification of MRJP 1 as an IgE-binding protein. Biosci Biotechnol Biochem 2011;75:556-60. PMID: 21389615

93. Silici S, Ekmekcioglu O, Kanbur M, Deniz K. The protective effect of royal jelly against cisplatin-induced renal oxidative stress in rats. World J Urol 2011;29:127-32. doi: 10.1007/ s00345-010-0543-5

94. Siavash M, Shokri S, Haghighi S, Mohammadi M, Shahtalebi MA, Farajzadehgan Z. The efficacy of topical Royal Jelly on diabetic foot ulcers healing: A case series. J Res Med Sci 2011;16:904-9. PMID: 22279458

95. Lercker G, Caboni MF, Vecchi MA, Sabatini AG, Nanetti A. Characterization of the main constituents of royal jelly 410 . Apicoltura 1992;8:27-37.

96. Oribe E, Arioka T, Fukuda K, Tatefuji T, Hashimoto K, Maeda K. Moisturizing effect of royal jelly extract and its mechanism on skin. J Dermatol 2010;37:77.

97. Abdelatif M, Yakoot M, Etmaan M. Safety and efficacy of a new honey ointment on diabetic foot ulcers: a prospective pilot study. J Wound Care 2008;17:108-10. PMID: 18376651

98. Planta von A. [Über den Futtersaft der Bienen, in German]. Hoppe-Seylers Zeitsch Physiol Chem 1888;12:327-54.

99. Lercker G. [La gelatina reale: composizione, autenticità ed dulterazione, in ltalian]. U: Atti del Convegno "Strategie per 
la valorizzazione dei prodotti dell'alveare". Campobasso: Università degli Studi del Molise; 2003. str. 67-81.

100. Bogdanov S, Bieri K, Gremaud G, Iff D, Känzig A, Seiler K, Stöckli H, Zürcher K. Swiss Food Manual: Gelée Royale. Berne: Bienenprodukte, BAG, Swiss Federal Office for Public Health; 2004.

101. Li Jk, Wang T, Peng Wj. Comparative analysis of the effects of different storage conditions on major royal jelly proteins. J Apicult Res 2007;46:73-80.

102. Kosińska, A, Karamać M, Penkacik K, Urbalewicz A, Amarowicz R. Interactions between tannins and proteins isolated from broad bean seeds (Vicia faba Major) yield soluble and non-soluble complexes. Eur Food Res Technol 2011;233:213-22.

103. Nagai T, Inoue R. Preparation and the functional properties of water extract and alkaline extract of royal jelly. Food Chem 2004;84:181-6. doi: 10.1016/S0308-8146(03)00198-5

104. Samaranayaka AGP, Li-Chan ECY. Food-derived peptidic antioxidants: A review of their production, assessment, and potential applications. J Funct Foods 2011;3:229-54. doi: 10.1016/j.jff.2011.05.006

105. Shahidi F, Zhong Y. Revisiting the polar paradox theory: a critical overview. J Agric Food Chem 2011;59:3499-504. doi: $10.1021 / \mathrm{jf} 104750 \mathrm{~m}$

106. Boselli E, Caboni MF, Sabatini AG, Marcazzan GL, Lercker G. Determination and changes of free amino acids in royal jelly during storage. Apidologie 2003;34:129-37. doi: 10.1051/apido:2003011

107. Terada Y, Narukawa M, Watanabe T. Specific hydroxy fatty acids in royal jelly activate TRPA1. J Agric Food Chem 2011;59:2627-35. doi: 10.1021/jf1041646

108. Antinelli JF, Zeggane S, Dav Ico R, Rognone C, Faucon JP, Lizzani L. Evaluation of (E)-10-hydroxydec-2-enoic acid as a freshness parameter for royal jelly. Food Chem 2003;80:859. doi: 10.1016/S0308-8146(02)00243-1

109. Ferioli F, Marcazzan GL, Caboni MF. Determination of(E)10-hydroxy-2-decenoic acid content in pure royal jelly: A comparison between a new CZE method and HPLC. J Sep Sci 2007;30:1061-9. PMID: 17566341

110. Lercker G, Caboni MF, Conti LS, Ruini F, Giordani G. Components of royal jelly: I. Identification of the organic acids. Lipids 1981;16:912-9. doi: 10.1007/BF02534997

111. Lercker G, Caboni MF, Conti LS, Ruini F, Giordani G. Components of royal jelly: II. The lipid fraction, hydrocarbons and sterols. J Apicult Res 1982;21:178-84.
112. Lercker G, Caboni MF, Vecchi MA, Sabtini AG, Nanetti, A. [Caratterizzazione dei principali costituenti dellagelatina reale, in Italian]. Apicoltura 1993;8:27-37.

113. Stocker A. Isolation and characterisation of substances from Royal Jelly. [PhD thesis]. Orléans: Université d'Orléans; 2003.

114. Howe SR, Dimick PS, Benton AW. Composition of freshly harvested and commercial royal jelly. J Apicult Res 1985;24:52-61.

115. Daniele G, Casabianca HH. Sugar composition of French Royal Jelly for comparison with commercial and artificial sugar samples. Food Chem 2012;134:1025-9. doi: 10.1016/ j.foodchem.2012.03.008

116. Ricciardelli D’Albore G. [Analisi microscopica del miele edella gelatina reale: possibilità di applicazione e limiti, in Italian]. Boll Acc Gioenia Sci Nat Catania 1986;19:45-60.

117. Ricciardelli D'Albore G, Battaglini M, Bernardini M. [Origine géographique de la Gelée royale, in Italian]. Apidologie 1978;9:1-17. doi: 10.1051/apido:19780101

118. Serra Bonvehi J. Sugar, acidity and $\mathrm{pH}$ royal jelly. Determination of tryptophan in bee pollen and royal jelly by high-performance liquid chromatography with fluorescence detection. Ann Bromatol 1992;44:65-9.

119. Zhang JZ, Xue XF, Zhou JH, Chen F, Wu LM, Li Y, Zhao J. Determination of tryptophan in bee pollen and royal jelly. Biomed Chromatogr 2009;23:994-8. doi: 10.1002/ bmc. 1213

120. Boselli E, Caboni MF, Lercker G, Marcazzan GL, Sabatini AG, Baggio A, Prandin L. [Valutazione di produzioni apistiche: Gelatina reale e cera, in Italian]. U: Sabatini AG, Bolchi Serrini G, Frilli F, Porrini C, editors. Il ruolo della ricerca in apicoltura. Bologna: Litosei; 2002. str. 321-9.

121. Marconi E, Caboni MF, Messia MC, Panfili G. Furosine: A suitable marker for assessing the freshness of royal jelly. J Agric Food Chem 2002;50:2825-9. PMID: 11982406

122. Messia MC, Caboni MF, Marconi E. Storage stability assessment of freezedried royal jelly by furosine determination. J Agric Food Chem 2005;53:4440-3. PMID: 15913307

123. Zheng HQ, Hu FL, Dietemann V. Changes in composition of royal jelly harvested at different times: consequences for quality standards. Apidologie 2011;42:39-47. doi: 10.1051/ apido/2010033

124. Rosmilah M, Shahnaz M, Patel G, Lock J, Rahman D, Masita A, Noormalin A. Characterization of major allergens of royal jelly Apis mellifera. Trop Biomed 2008;25:243-51. PMID: 19287364 


\section{Summary}

\section{ROYAL JELLY: COMPONENT EFFICIENCY, ANALYSIS, AND STANDARDISATION}

Royal jelly is a viscous substance secreted by the hypopharyngeal and mandibular glands of worker honeybees (Apis mellifera) that contains a considerable amount of proteins, free amino acids, lipids, vitamins, sugars, and bioactive substances such as 10-hydroxy-trans-2-decenoic acid, antibacterial protein, and $350-\mathrm{kDa}$ protein. These properties make it an attractive ingredient in various types of healthy foods. This article brings a brief review of the molecular mechanisms involved in the development of certain disorders that can be remedied by royal jelly, based on a selection of in vivo and in vitro studies. It also describes current understanding of the mechanisms and beneficial effects by which royal jelly helps to combat aging-related complications. Royal jelly has been reported to exhibit beneficial physiological and pharmacological effects in mammals, including vasodilative and hypotensive activities, antihypercholesterolemic activity, and antitumor activity. As its composition varies significantly (for both fresh and dehydrated samples), the article brings a few recommendations for defining new quality standards.

KEY WORDS: functional food, quality standardisation, chemical composition, bee products

\section{CORRESPONDING AUTHOR:}

\section{Nada Oršolić}

Sveučilište u Zagrebu, Prirodoslovno-matematički fakultet

Zavod za animalnu fiziologiju

Rooseveltov trg 6, 10000 Zagreb, Hrvatska

E-mail:norsolic@yahoo.com 